\title{
Efficacy of Miayalin G2 Suckericide on the yield of FCV tobacco
}

\section{Asad Ali Khan, Fazal Munsif, Muhammad Zahir, Muhammad Shoaib, Ziaullah, Mohmmmad Nauman Khan, Shah Fahad and Muhammad Rabnawaz Khan}

Department of Agronomy, Faculty of Crop Production Sciences, The University of Agriculture, Peshawar, KPK, Pakistan.

Corresponding Author: Dr. Asad Ali Khan Email Address: asad_g04@yahoo.com

\section{Citation.}

Asad Ali Khan, Fazal Munsif, Muhammad Zahir, MuhammadShoaib, Ziaullah, Mohmmmad Nauman Khan, Shah Fahad and Muhammad Rabnawaz Khan. Efficacy of Miayalin G2 suckericide on the yield of FCV tobacco. Pure and Applied Biology Vol. 4, Issue 2, 2015, pp 181-186.

Received: $16 / 02 / 2015$ Revised: 07/05/2015

Accepted: 13/05/2015

\section{Abstract}

Topping followed by desuckering are very important operations for improving leaf yield of tobacco, by larger size and weight of leaves. Although topping may be done once, removal of secondary suckers takes place several times during the season. So application of suckericide within health limit concentrations to suppress the growth of suckers are very important. A field experiment was conducted at Pakistan Tobacco Board Research Station Khan GarhiMardan, during 2011-2012 to study the efficacy of Miayaling2 to find out its optimum concentration for suckers control and enhancing leaf yield of FCV tobacco. The treatment composed of control (no suckering) with three levels of Miayaling2 (900 ml ha ${ }^{-1}, 1000 \mathrm{ml} \mathrm{ha}^{-1}$ and $1200 \mathrm{ml} \mathrm{ha}^{-1}$ ) arranged in RCB design with three replication. After 20 days of suckericide application, greater number of suckers plant ${ }^{-1}$ (3) was recorded from control plots while lower (2) in plots treated with $1200 \mathrm{ml}$ $\mathrm{ha}^{-1}$. Similarly higher leaf area $\left(729.3 \mathrm{~cm}^{2}\right)$ and cured leaf yield $\left(2560 \mathrm{~kg} \mathrm{ha}^{-1}\right)$ was recorded in $1200 \mathrm{ml} \mathrm{ha}^{-1}$ treated plots while lower leaf area $\left(657.3 \mathrm{~cm}^{2}\right)$ and cured leaf yield $\left(2350 \mathrm{~kg} \mathrm{ha}^{-1}\right)$ was obtained from control plots. The present study indicated that application of suckericide with $1200 \mathrm{ml} \mathrm{ha}^{-1}$ level suppress suckers well than and gave higher leaf yield of FCV tobacco.

Key words: Leaf yield; Miayaling 2; Suckericide; Tobacco

\section{Introduction}

Tobacco (Nicotiana tabacum L.) belongs to the family Solaneaceae is an important cash crop. In Pakistan it is the $2^{\text {nd }}$ prominent cash crop after sugarcane. Total area covered by tobacco in Pakistan is 49,000 ha which give 104,000 tons production [1]. In Khyber Pakhtunkhwa it is cultivated on 31,000 ha which give 78 tons production [2]. Tobacco contributes Rs 27.5 billion to the GDP (4.4\%) of Pakistan and employs nearly 1.2 million people. As $75 \%$ of the crop is grown in Khyber Pakhtunkhwa thus Tobacco is the most important cash crop of this province as compared to other cash crop and contributes Rs. $15.17 \mathrm{~b}$ as tax revenue to the economy 
of Pakistan [1]. Leaf yield is the main objective of farmers along with weighty and good quality. Many factors affecting tobacco leaf yield among which Suckers are the critical one. Tobacco produces a single stalk with a terminal or apical bud at the top. The terminal bud exhibits apical dominance. At each leaf axil lateral buds may be produced if the terminal bud is lost, removed or allowed to go completely to the production of flowers. These lateral buds are called "suckers" and grow especially fast after the removal of the terminal bud and the loss of apical dominance. These suckers become a drain on the nutrients of the plant due to its fast growth and also compete for light, moisture and space and hence affect the quantity as well as the quality consequently decrease farmers' income. Suckers not only deprive the plants from their essential nutrients but also harbor insect pests and disease organisms. These suckers can be removed by hand but it is laborious task and consumes a lot of labor and time [3]. Farmer uses different suckericides to control suckers but it is also of high importance to use such concentrations which would be economical. Suckericides control suckers and increase FCV yield however suckericides also have adverse effects on human health, the suckericide Maleic hydrazide $(\mathrm{MH})$ residue in food and tobacco is highly toxic causing CNS disturbances and liver damage. Likewise Prime plus is corrosive, moderately irritating to the eyes and mildly irritating to the skin. Repeated contact with the skin may cause sensitization (allergic) reactions in sensitive individuals. Prolonged inhalation may cause headache, dizziness, breathing difficulty, or nausea. Keeping in view the importance of the suckericides' application in Tobacco the experiment was initiated at Tobacco Research Station Khan Garhi Mardan to study the efficacy of miayaling-2 as suckericide in different concentrations and to find out appropriate concentration of this new product for the control of suckers and on yield of flue cured Virginia tobacco.

\section{Materials and Methods}

A field experiment entitled "Efficacy of Miayaling2 Suckericide on the yield of FCV tobacco was conducted at the Tobacco Research Station Khan GarhiMardan (KPK) during 2011-2012. Speight-G28 variety was sown which was imported from Winter Wille North Carolina America.

The texture of the soil was silt loam derived from loess plains soils, irrigated with the canal water of swat. The area lies between latitudes $33^{\circ} 40^{\circ}$ and $33^{\circ} 35^{\circ} \mathrm{N}$ and between longitudes of $71^{\circ} 15^{\circ}$ and $72^{\circ} 50^{\circ} \mathrm{E}$ with an average altitude of about $274 \mathrm{~m}$ above the sea level. Soils of the valley are composed of alluvium formed under the combined influence of either a sub-humid or a semiarid-subtropical hot continental climate with mean annual rainfall of about $580 \mathrm{~mm}$.

The experiment was conducted in RCB design using three replications. Plot size was $5.5 \mathrm{~m}$ by $2 \mathrm{~m}$ with 3 rows, $5.5 \mathrm{~m}$ long, having 10 plants in each row. The row to row distance was $90 \mathrm{~cm}$ while plant to plant distance was kept $60 \mathrm{~cm}$. Crop was raised by transplanting nursery rather than direct seedling in the field. So first nursery was raised in the month of December 2011 and then was transplanted in the 2nd week of March 2012. Before transplantation land was ploughed using cultivator and sub-soiler and then was worked with rotator for breaking of clods. NPK fertilizer was applied to supply 40-80-80 $\mathrm{kgha}^{-1}$ nitrogen, phosphorous and potassium respectively. After that ridges were made and transplantation was done on ridges following the recommended spacing. Irrigation was applied immediately after transplantation and then applied when needed and in all the crop was irrigated 10 
times up to completion of pickings. After establishment of the plants weeds were removed manually. Topping was done when more than $50 \%$ of heading completed in each plot and then suckericide miayaling-2 was applied in respective plots.

The four treatments were; $\mathrm{T} 1=$ Manual topping or No desuckering $\mathrm{T} 2=$ Minimum dose $=900 \mathrm{ml} \mathrm{ha}^{-1}$

$\mathrm{T} 3=$ Optimum dose $=1000 \mathrm{ml} \mathrm{ha}^{-1}$

$\mathrm{T} 4=$ Maximum dose $=1200 \mathrm{ml} \mathrm{ha}^{-1}$

To record number of leaves plant ${ }^{-1}$, the leaves of ten plants in each plot were counted and their means were then calculated. In each plot plant height of ten plants were measured with meter rod and then their means were calculated. After 20 days number of suckers plant ${ }^{-1}$ in each plot were recorded by counting the number of suckers in 10 plants and then means were calculated. Green weight of Suckers plant ${ }^{-1}$ was calculated by taking suckers from 10 plants randomly in each plot and then the total weight was divided by the number of plants to get the mean. By curing or drying the same number of suckers we took in green weight, dry weight of sucker's plant ${ }^{-1}$ was calculated. Green weight plot $^{-1}$ was measured after each picking by weight balance. Total four pickings were taken.After determining green weight plot $^{-1}$, number of green leaves per $\mathrm{KG}$ was calculated as;

Number of green leaves $\mathrm{KG}^{-1}=$

No of leaves in the determined weight $\mathrm{x} \mathrm{kg}$ Weight determined

The same pickings taken in green weight were then cured and their weight was determined by weight balance.

After taking cured weight plot $^{-1}$, number of cured leaves per $\mathrm{KG}$ was calculated as;

Number of cured leaves $\mathrm{KG}^{-1}=$

No of leaves in the determined weight $\mathrm{x} \mathrm{kg}$

Cured weight determined
In each plot, length and width of $5^{\text {th }}, 10^{\text {th }}$ and $15^{\text {th }}$ leaf of 10 plants was measured and average was recorded. For average leaf area, the product of length and width of each position was added and divided by 3 and then multiplied with correction factor 0.644. Leaf area $=$ leaf Length $\mathrm{x}$ leaf width $\mathrm{x} 0.644$ The leaf yield in $\mathrm{kg} \mathrm{ha}^{-1}$ of each plot was calculated by the following formula;

Cured leaf weight $\left(\mathrm{kg} \mathrm{ha}^{-1}\right)=$

$$
\frac{\text { cured leaf weight } \text { plot }^{-1}}{\text { Area harvested }} \times 10000 \mathrm{~m}^{2}
$$

Data collected was subjected to analysis of variance (ANOVA) according to the methods described by [4], and means between the treatments were compared by least significant difference test $(\mathrm{P} \leq 0.05)$.

\section{Results and Discussion}

Number of Leaves Plant ${ }^{-1}$

Statistical analysis of the data revealed that different concentrations of Miayaling-2 suckericide had a significant effect on the number of leaves plant ${ }^{-1}$. It can be seen from the mean values in table 1 that maximum number of 24.3 leaves plant ${ }^{-1}$ were produced by plots treated with $1200 \mathrm{mha}^{-1}$ followed by plots treated with $1000 \mathrm{ml} \mathrm{ha}^{-1}$ (22.5 leaves plant $^{-1}$ ) which were statistically significantly different from plots where only manual topping was done. It can be concluded from these results that sucker control might diverted nutrients to the plant leaves and hence increased number of leaves plant ${ }^{-1}$. These results coincided with the results of [3] who reported that chemically desuckered plants resulted in greater number of leaves.

\section{Plant height}

Suckericide levels have significantly affected plant height. Higher plant height was obtained in plots treated with $1200 \mathrm{mlha}^{-}$ 1 which was at par with plots treated manually. Similar results were obtained by [5] who reported that chemically topped plants usually resulted in taller plants, 
greater number of leaves and shorter, narrower top leaves.

Number of suckers plant ${ }^{-1}$

Number of suckers plant ${ }^{-1}$ was significantly affected by different concentrations of the suckericide. Mean values of the data in table 1 indicated that maximum number of suckers plant ${ }^{-1}$ (2.5 suckers plant ${ }^{-1}$ ) were produced by plots where manual topping was done only which were statistically significantly different from plots treated with $1200 \mathrm{ml} \mathrm{ha}^{-1}\left(2.0\right.$ suckers plant $\left.^{-1}\right)$ followed by plots treated with $1000 \mathrm{ml} \mathrm{ha}^{-}$ ${ }^{1}\left(2.2\right.$ suckers plant $\left.{ }^{-1}\right)$. These results coincided with the results of [3] who concluded that suckers were best controlled by chemical suckericide (Pendimethalin 33Ec).

Green weight of suckers plant ${ }^{-1}$
Different concentrations of suckericide had significantly affected green weight of suckers plant ${ }^{-1}$. It can be seen from mean values in table 1 that maximum green weight of suckers plant ${ }^{-1}(73.3 \mathrm{gm})$ was recorded in plots where manual topping was done which were statistically significantly different from plots treated with $1200 \mathrm{ml} \mathrm{ha}^{-1}$ $(56.7 \mathrm{gm})$. These results show that suckers were best controlled by using this concentration of suckericide and had thus provided the plants with more nutrients which would otherwise be exploited by the suckers and hence increased green weight of suckers' plant $^{-1}$. These results are in close proximity with the findings of [6]who concluded that suckericide (Tamex 4.00 Lha $^{-1}$ ) reduced suckers fresh weight plant ${ }^{-1}$ as compared with manual desuckering.

Table-1. Number of leaves plant ${ }^{-1}$, Plant height, number of suckers plant ${ }^{-1}$ and green weight of suckers plant ${ }^{-1}$ of $\mathrm{FCV}$ tobacco as affected by different levels of Miayaling2 suckericide.

\begin{tabular}{|c|c|c|c|c|}
\hline $\begin{array}{l}\text { Suckericide } \\
\text { Levels }\end{array}$ & $\begin{array}{l}\text { Number of } \\
\text { leaves plant }{ }^{-1}\end{array}$ & $\begin{array}{l}\text { Plant } \\
\text { height }(\mathbf{c m})\end{array}$ & $\begin{array}{l}\text { Number of } \\
\text { suckers plant }^{-1}\end{array}$ & $\begin{array}{l}\text { Green weight of } \\
\text { suckers plant }^{-1}(\mathrm{gm})\end{array}$ \\
\hline Manual topping & $20.7 \mathrm{bc}$ & 106.3 & $2.5 \mathrm{a}$ & $73.3 \mathrm{a}$ \\
\hline $900 \mathrm{ml} \mathrm{ha}^{-1}$ & $21.6 \mathrm{~b}$ & 107.3 & $2.3 \mathrm{a}$ & $60.0 \mathrm{~b}$ \\
\hline $1000 \mathrm{ml} \mathrm{ha-1}$ & $22.5 \mathrm{~b}$ & 113 & $2.2 \mathrm{ab}$ & $62.3 \mathrm{~b}$ \\
\hline $1200 \mathrm{ml} \mathrm{ha}^{-1}$ & $24.3 \mathrm{a}$ & 116.3 & $2.0 \mathrm{~b}$ & $56.7 \mathrm{~b}$ \\
\hline LSD0.05 & 1.5 & Ns & 0.22 & 7.6 \\
\hline
\end{tabular}




\section{Dry weight of suckers plant ${ }^{-1}$}

Statistical analysis of the data revealed that different concentrations of suckericide had significantly affected dry weight of suckers' plant $^{-1}$. Maximum dry weight $(21 \mathrm{gm})$ was recorded in plots treated with manual topping only while minimum dry weight $(13.7 \mathrm{gm})$ was noted in plots treated with $1200 \mathrm{ml} \mathrm{ha}^{-1}$ which is statistically significantly different from the previous one as shown in table 2. Similar results were obtained by [3] and [6] that chemical desuckering decreased dry weight of suckers plant $^{-1}$ in FCV tobacco.

\section{Green weight plot $^{-1}$}

Analysis of the data revealed that green weight plot $^{-1}$ had significantly affected by different concentrations of suckericide. Maximum green weight $(32.9 \mathrm{~kg})$ plot $^{-1}$ was recorded in plots treated with $1200 \mathrm{ml} \mathrm{ha}^{-1}$ while minimum green weight $(24.9 \mathrm{~kg})$ was recorded in plots where manual topping was done only. These results may be due to the nutrients diversion to the leaves from suckers control.

Number of green leaves $\mathbf{~ k g}^{-1}$

Statistical analysis of the data revealed that different concentrations of the suckericide had no effect on the number of green leaves $\mathrm{kg}^{-1}$. The nutrients might be exploited by the lateral leaves for increasing their area and hence decreased number of leaves.

\section{Cured weight plot $^{-1}$}

Cured weight plot $^{-1}$ was significantly affected by suckericide concentration. The mean values of the treatments are nonsignificantly different from each other, however higher cured weight $(4.27 \mathrm{~kg})$ plot $^{-1}$ was recorded in plots treated with $1200 \mathrm{ml}$ $\mathrm{ha}^{-1}$ while lower cured weight $(3.92 \mathrm{~kg})$ plot $^{-1}$ was recorded in manually topped plots (Table2).

Table-2. $\quad$ Effect of concentration of Miayaling-2 Suckericide on dry weight (gm.) of suckers plant ${ }^{-1}$, green weight $(\mathrm{kg})$ plot $^{-1}$, number of green leaves $\mathrm{kg}^{-1}$ and cured weight plot $^{-1}(\mathrm{~kg})$

\begin{tabular}{|c|c|c|c|c|}
\hline Suckericide & $\begin{array}{l}\text { Dry weight of suckers } \\
\text { plant }^{-1}(\mathrm{gm})\end{array}$ & $\begin{array}{l}\text { Green weight } \\
\text { plot }^{-1}(\mathrm{~kg})\end{array}$ & $\begin{array}{l}\text { Number of green } \\
\text { leaves } \mathrm{kg}^{-1}\end{array}$ & $\begin{array}{l}\text { Cured weight } \\
\text { plot }^{-1}(\mathrm{~kg})\end{array}$ \\
\hline $\begin{array}{l}\text { Manual } \\
\text { topping }\end{array}$ & $21 \mathrm{a}$ & $24.9 \mathrm{~b}$ & 24.9 & $3.92 \mathrm{a}$ \\
\hline $900 \mathrm{ml} \mathrm{ha}{ }^{-1}$ & $18 \mathrm{a}$ & $24.5 \mathrm{~b}$ & 26.0 & $4.07 \mathrm{a}$ \\
\hline $1000 \mathrm{ml} \mathrm{ha}{ }^{-1}$ & $15.3 \mathrm{ab}$ & $24.8 \mathrm{~b}$ & 25.5 & $4.15 \mathrm{a}$ \\
\hline $1200 \mathrm{ml} \mathrm{ha}{ }^{-1}$ & $13.7 \mathrm{~b}$ & $32.9 \mathrm{a}$ & 24.1 & $4.27 \mathrm{a}$ \\
\hline LSD0.05 & 3.8 & 3.1 & ns & 0.05 \\
\hline
\end{tabular}

\section{Leaf area}

Leaf area was significantly affected by different concentrations of the suckericide. It is clear from the Table 3 that maximum leaf area $\left(729.3 \mathrm{~cm}^{2}\right)$ was recorded in plots treated with $1200 \mathrm{ml} \mathrm{ha}^{-1}$ followed by plots treated with $1000 \mathrm{ml} \mathrm{ha}$ which were statistically significantly different from manually topped plots. These results may be due to the more nutrients diverted from suckers to the leaves of the plants and hence increased leaf area. Similar results were also reported by [3] who observed that leaf area 
was higher in plants treated chemical suckericide (Pendimethalin 33Ec).

\section{Leaf yield}

Statistical analysis of the data showed that leaf yield was significantly affected by suckers control through different concentrations of Miayaling2 suckericide. Mean values of the data (Table 3) are not significantly different however maximum leaf yield $\left(2560 \mathrm{~kg} \mathrm{ha}^{-1}\right)$ was recorded in plots treated with $1200 \mathrm{ml} \mathrm{ha}^{-1}$ concentration followed by plots treated with $1000 \mathrm{ml} \mathrm{ha}^{-1}$ while minimum leaf yield $\left(2350 \mathrm{~kg} \mathrm{ha}^{-1}\right)$ was recorded in manually topped plots. Similar results were obtained by [6] and [3] who reported that chemical suckericides gave maximum cured leaf yield as compared with manual desuckering.

Table -3. Leaf area $\left(\mathrm{cm}^{2}\right)$ and leaf yield $\left(\mathrm{Kg} \mathrm{ha}^{-1}\right)$ as affected by different concentration of Miayaling-2 Suckericide.

\begin{tabular}{|c|c|c|}
\hline Suckericide & Leaf area $\left(\mathrm{cm}^{2}\right)$ & $\begin{array}{l}\text { Leaf yield } \\
\left(\mathrm{kg} \mathrm{ha}^{-1}\right)\end{array}$ \\
\hline Manual topping & $657.3 \mathrm{~b}$ & 2350 \\
\hline $900 \mathrm{ml} \mathrm{ha}^{-1}$ & $669.6 \mathrm{ab}$ & 2430 \\
\hline $1000 \mathrm{ml} \mathrm{ha}^{-1}$ & $697.7 \mathrm{a}$ & 2490 \\
\hline $1200 \mathrm{ml} \mathrm{ha}^{-1}$ & $729.3 \mathrm{a}$ & 2560 \\
\hline LSD0.05 & 39.8 & 13.8 \\
\hline
\end{tabular}

\section{Conclusion}

From this experiment it is concluded that Miayaling 2 at the rate of $1200 \mathrm{ml} \mathrm{ha}^{-1}$ effectively control suckers which ultimately gave high leaf area and leaf yield.

\section{Refrences}

1 MINFA. (2010). Ministry for Food, Agriculture and Livestock. Agricultural Statistics of Pakistan. Government of Pakistan.

2 MINFA. (2007). Ministry for Food, Agriculture and Livestock. Agricultural Statistics of Pakistan. Government of Pakistan.

3 Bakhat J, Khalil SK, Shafi M, Rehman A, Akhter S \& Jan MI
(2007. Comparative effect of suckericides and manual desuckering on the yield and quality of FCV tobacco. Sarhad J. Agric. 23(1): 11-15.

4 Steel RGD \& Torrei JH (1980). Principles and procedure of statistics. McGraw Hill. New York. USA.

5 Long RS, Jones LJ \& Wilkinson AC (1990). Chemically topping mammoth cultivars offlue-cured tobacco. Tobacco International 192: 48-50.

6 Qahar A, shah P, Khan ZH \& Shah SMA (2006). Effect of chemical suckericideson yield and quality of FCV tobacco. Sarhad J. Agric.

22(2):

193-197. 